\title{
Physicochemical Evaluation Of Croton Wagneri Müll Arg. Powder (Moshquera)
}

\author{
Ernesto Cornelio Terán Portelles, M. Sc. \\ Eva Salas Olivet, M. Sc. \\ University of Havana, Cuba, Institute of Pharmacy and Food \\ Jhunior Abrahan Marcía Fuentes, M. Sc. \\ National University of Agriculture, Faculty of Technological Sciences, \\ Honduras
}

Doi:10.19044/esj.2020.v16n24p278 URL:http://dx.doi.org/10.19044/esj.2020.v16n24p278

\begin{abstract}
:
The Croton wagneri Müll. Arg. commonly known as moshquera is a wild plant endemic to Ecuador. It grows on several altitudinal floors ranging from $1000 \mathrm{~m}$ (3280 ft) to $3012 \mathrm{~m}(9881 \mathrm{ft})$ above sea level. The objectives of this study were to characterize the powder of the dehydrated leaves of the Croton wagneri Müll. Arg. (moshquera), its fatty acid composition, and to investigate its physicochemical properties. The physical characteristics of the leaves showed heterogeneous green color, herbaceous odor, characteristic bitter and astringent taste. The dehydrated leaf flour of the moshquera plant

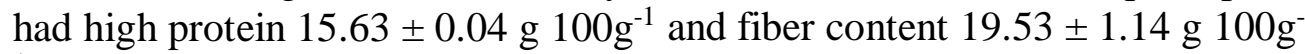
1 . Oleic acid was found the highest in the fatty acid analysis and there was a significant content of mono and polyunsaturated fats. The moshquera plant may be incorporated into foods to increase their nutritional value. Further research should be done to investigate the full applications and uses of this plant.
\end{abstract}

Keywords: Nutrients, Food, Dehydrated leafs, Protein.

\section{Introduction:}

Medicinal plants have several benefits for humanity, and one of them is their medicinal contribution due to the presence of phytochemicals and antioxidants, which makes these bioactive compounds the main source of nutraceuticals (Marcía et al., 2020). This information will help determine their potential uses in fields such as agronomy, agroindustry and the food industry. Some components of these plants could also be used in pharmaceutical applications. From the earliest times, many societies have utilized plants as their main source of energy and food (Hu, 2003). Each community have 
grouped these plants depending on their availability and the necessities of the population (Ouborg, Piquot, \& Van Groenendael, 1999). If these foods have a significant amount of nutrients there are usually classify as regulator foods. These foods should provide vitamins and minerals necessary to maintain the structural integrity and function of the organism (Rojas, Uribe, Martínez, \& Niño, 2009). Nowadays, researchers are investigating new native and endemic plants such as Croton wagneri to evaluate their uses and applications.

Croton Wagneri, commonly known as moshquera blanca, belongs to the Euphorbiaceae family and its genus Croton has over 1500 species and is distributed mainly in South America, Central America and the northern part of Africa (De la Torre, Navarrete, Muriel, Macía, \& Balslev, 2008). C. Wagneri is a small tree or bush that has multiple branches and can grow up to $4 \mathrm{~m}$. Its leaves have a spade shape and are approximately $5 \mathrm{~cm}$ long and have a very distinctive greenish coffee color (González, Pérez, Monan, \& Rodríguez, 2020). Many cultures have consumed the leaves of native's plants to nourish their population and moshquera may have the potential to be incorporated in people's foods.

In Brazil, it is easy to find juice concentrates and isolated protein cakes from the leaves of extruded cassava. These juices can reach to about $70 \%$ protein and the isolated protein to about $90 \%$. Because of the high content of protein in these foods, they can be considered functional foods of easy transformation, distribution and consumption (Le Guerroué, Douillard, Cereda, \& Chiarello, 1996). In Indonesia, the young leaves of cassava are considered a common food and their production is estimated to be about 0.50.7 million tonnes/year. The consumption of $400 \mathrm{~g}$ of cassava leaves per capita per day would provide about $45-50 \mathrm{~g}$ of vegetable protein (Wargiono, Richana, \& Hidajat, 2011). The leaves of cassava have a high content of nutrients which include: zinc, copper, phosphorous, magnesium, potassium and iron (Howeler, 2002). They also contain beta-carotene, vitamin A, vitamin C, B1, B6, B12, pantothenic acid which prevents deterioration of the skin, and folic acid a potent antianemic vitamin (Giraldo, Velasco, \& Aristizabal, 2006). Another plant originally from Southeast Asia, Moringa oleifera, commonly known as moringa have been used in foods for breads, cookies, and meat products (Oyeyinka \& Oyeyinka, 2018). Moringa in meat products have functions as an antioxidant and preservative (Doménech Asensi, Durango Villadiego, \& Ros Berruezo, 2017). In the country of Chile, dehydrated quinoa leaves flour have been used to parcially subsititute wheat flour in the preparation of cookies and breads (Sáez-Tonacca, Aravena-Narbona, \& Díaz Ramírez, 2018).

Many native plants such as the ones previously mentioned have the potential as sources of protein, fiber, energy and overall nutrition. Their content of antioxidants would favor mechanisms to increase immunity in the 
body and eliminate free radicals (Soni \& Sosa, 2013). These plants can substitute and provide alternatives for individuals in many regions of the world (Sharapin, 2001). It has been documented that Croton wagneri Müll. Arg is a good source of flavonoid compounds, terpenes, alkaloids, and unsaturated fatty acids. It has also been reported as a cicatrizing agent, gastroprotective, anti-inflammatory, antiseptic, and hemostatic medicine (Altamirano Pérez, 2015) (Barrera, 2016) (Pino, Terán-Portelles, Hernández, Rodeiro, \& Fernández, 2018). To the best of our knowledge, the fatty acid analysis and characterization of the powder of the leaves of $C$. wagneri has not been carried out. The objective of this work was to characterize the powder of the dehydrated leaves of the Croton wagneri Müll. Arg. (Moshquera), to investigate its nutritional composition and mineral content

\section{Material and method:}

\section{Collection of Croton wagneri leaves}

The moshquera plant samples from the province of Imbabura, city of Ibarra, parish of San Antonio de Ibarra, Ecuador were collected at an elevation of $2380 \mathrm{~m}$ above sea level (Table 1) (Figure 1). A sample of Croton wagneri Müll. Arg. was provided to the herbarium located in the Pontifical Catholic University of Quito with number QCA 165692. A physical examination and screening process of the moshquera leaves were implemented to ensure uniformity in the product for its processing.

Table 1. Taxonomical classification of the plant Croton wagneri Müll. Arg

\begin{tabular}{cc}
\hline \multicolumn{2}{c}{ Scientific classification of moshquera } \\
\hline Kingdom & Plantae \\
Division & Mangniliophyta \\
Class & Magnoliopsida \\
Order & Euphorbiales \\
Family & Euphorbiaceae \\
Genus & Croton \\
Specie & Croton wagneri Müll. Arg. \\
\hline \multicolumn{2}{c}{ Source: Zhofre (2012) }
\end{tabular}

\section{Processing of the materials}

Fresh leaves were placed in a digital scale BS 2202S Sartorius (Göttingen, Germany) for a total weight of $0.6 \mathrm{~kg}$. The leaves were then washed with water and $1 \%$ sodium hypochlorite to eliminate the microbial load. The moshquera leaves were dried in a convection oven O.R.L model SR0110 (Buenos Aires, Argentina) with a temperature of $40{ }^{\circ} \mathrm{C}$ for 12 hours to obtain a moisture level of less than $4 \%$. The dried leaves were grinded to obtain a powder of less than $3 \mathrm{~mm}$ using a knife mill grinder. This process resulted in $150 \mathrm{~g}$ of dried moshquera leave flour. All the powder was packaged in polyethylene bags and stored at room temperature. 


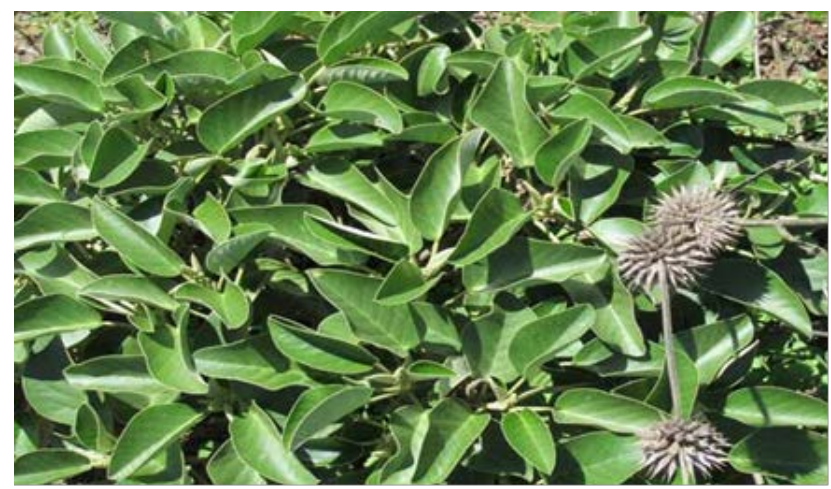

Figure 1. Leaves of the moshquera plant Croton wagneri Müll. Arg.

The analysis for this study were done according to standards. Protein content was determined with the microkjeldahl method AOAC 981.10, crude fat with AOAC 2003.06, fiber content with INEN 522, ash content with method AOAC 923.03, moisture content with AOAC 925.05, total carbohydrate with AOAC 986.25, total calories with the CAC/GL2: 1985 method, and fatty acid analysis AOAC 966.06.

\section{Results and discussion:}

Table 2. Physical analysis of the leaves of Croton wagneri

\begin{tabular}{cc}
\hline Test & Response \\
\hline Color & Heterogeneous green \\
Odor & Herbaceous \\
Taste & Bitter; Astringent \\
Texture & Membranous \\
\hline
\end{tabular}

Heterogeneous green color, herbaceous odor, characteristic bitter and astringent taste were found due to the presence of bitter principles secondary metabolites, and a membranous texture (Table 2). Dehydrated leaf flour of the moshquera plant allowed to verify the presence of protein $15.63 \pm 0.04 \mathrm{~g} \mathrm{100 \textrm {g }}$

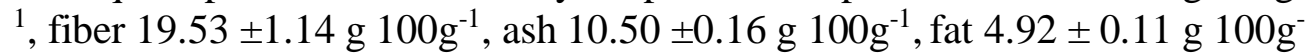

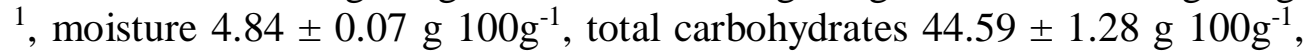

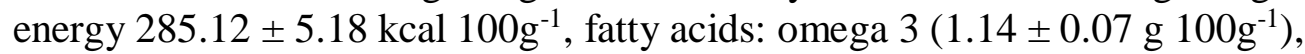

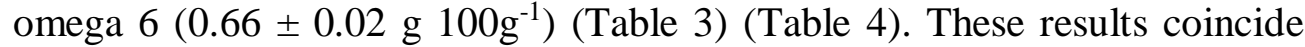
with that expressed by Butt and Batool (2010) and Akende et al., (2010), in

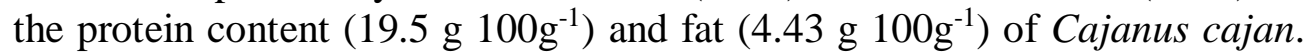
However, the chemical quality of $C$. wagneri is lower compared to soy (Glycine max) (Navarro et al., 2014) and higher than that reported by Marcía et al., (2019), compared to cassava flour dehydrated. 
Results showed that the moshquera leaves flour had a high protein and fiber

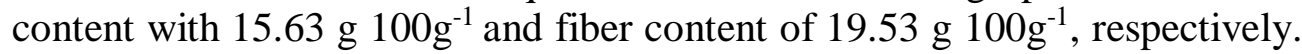
For a dehydrated plant leaf this will be considered relatively high (Ghaly \& Alkoaik, 2010). In a study that investigated the dehydrated quinoa leaves in

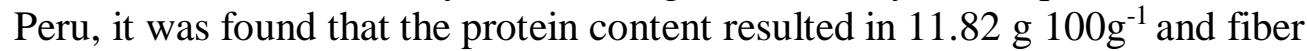

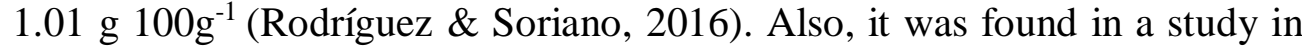
Colombia that dehydrated cassava leaves's fiber were reported to have 11.05 g $100 \mathrm{~g}^{-1}$ (Buitrago, 1990). The amount of protein in the moshquera plant compared to the quinoa leaves were significantly greater.

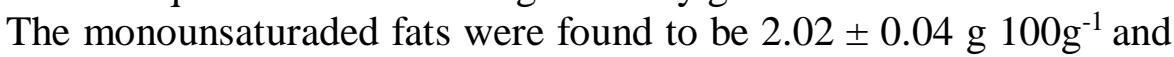

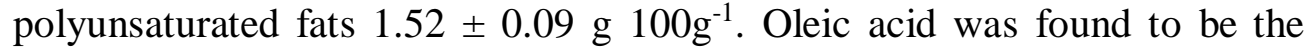
highest in the fatty acid analysis out of all the fatty acids. Oleic acid has been described as the main component in olive oil protecting breast cancer. According to Win (2005), oleic acid synergistically enhances cancer drug effectiveness and lowers blood levels of cholesterol and lowers the risk of heart problems. The fatty acid analysis and characterization of the leaves of $C$. wagneri are fundamental since they will help researchers from the academia and several industries to develop and evaluate new applications and uses for this plant.

Table 3. Nutritional composition of the dehydrated leaves of Croton wagneri

\begin{tabular}{|c|c|}
\hline Analysis & Average \pm Standard deviation \\
\hline Moisture (g 100g $\mathrm{g}^{-1}$ ) & $4.84 \pm 0.07$ \\
\hline Protein $\left(\mathrm{g} 100 \mathrm{~g}^{-1}\right)$ & $15.63 \pm 0.04$ \\
\hline Fat $\left(\mathrm{g} 100 \mathrm{~g}^{-1}\right)$ & $4.92 \pm 0.11$ \\
\hline Ash $\left(\mathrm{g} 100 \mathrm{~g}^{-1}\right)$ & $10.50 \pm 0.16$ \\
\hline Fiber $\left(\mathrm{g} 100 \mathrm{~g}^{-1}\right)$ & $19.53 \pm 1.14$ \\
\hline Carbohydrate $\left({\left.\mathrm{g} 100 \mathrm{~g}^{-1}\right)}\right.$ & $44.59 \pm 1.28$ \\
\hline Energy kcal/ 100g & $285.12 \pm 5.18$ \\
\hline
\end{tabular}

Table 4. Fatty acid analysis of the dehydrated leaves of Croton wagneri Müll Arg

Compound name

$\begin{array}{cc}\text { Butyric acid }\left(\mathrm{g} 100 \mathrm{~g}^{-1}\right) & 0.10 \pm 0.00 \\ \text { Caproic acid }\left(\mathrm{g} 100 \mathrm{~g}^{-1}\right) & 0.10 \pm 0.00 \\ \text { Caprylic acid }\left(\mathrm{g} 100 \mathrm{~g}^{-1}\right) & 0.10 \pm 0.00 \\ \text { Capric acid }\left(\mathrm{g} 100 \mathrm{~g}^{-1}\right) & 0.10 \pm 0.00 \\ \text { Lauric acid }\left(\mathrm{g} 100 \mathrm{~g}^{-1}\right) & 0.10 \pm 0.00 \\ \text { Myristic acid }\left(\mathrm{g} 100 \mathrm{~g}^{-1}\right) & 0.13 \pm 0.02 \\ \text { Myristoleic acid }\left({\left.\mathrm{g} 100 \mathrm{~g}^{-1}\right)}^{\text {Pac }}\right. & 0.10 \pm 0.00 \\ \text { Pentadecanoic acid }\left({\left.\mathrm{g} 100 \mathrm{~g}^{-1}\right)}^{\text {Palmitic acid }\left(\mathrm{g} 100 \mathrm{~g}^{-1}\right)}\right. & 0.10 \pm 0.00 \\ \end{array}$




\begin{tabular}{|c|c|}
\hline Palmitoleic acid (g 100g ${ }^{-1}$ ) & $0.10 \pm 0.00$ \\
\hline Margaric acid (g 100g-1) & $0.10 \pm 0.00$ \\
\hline Heptadecenoic acid (g 100g ${ }^{-1}$ ) & $0.10 \pm 0.00$ \\
\hline Stearic acid (g 100g ${ }^{-1}$ ) & $0.21 \pm 0.01$ \\
\hline Oleic acid (g 100g $\mathrm{g}^{-1}$ ) & $1.92 \pm 0.04$ \\
\hline Elaidic acid (g 100g ${ }^{-1}$ ) & $0.10 \pm 0.00$ \\
\hline Linoleic acid (g 100g-1) & $0.38 \pm 0.02$ \\
\hline alpha-Linolenic acid (g 100g-1) & $0.41 \pm 0.02$ \\
\hline Linoelaidic acid (g 100g ${ }^{-1}$ ) & $0.10 \pm 0.00$ \\
\hline Arachidic acid (g 100g-1) & $0.10 \pm 0.00$ \\
\hline Eicosenoic acid (g 100g-1) & $0.10 \pm 0.00$ \\
\hline Arachidonic acid $\left(\mathrm{g} 100 \mathrm{~g}^{-1}\right)$ & $0.27 \pm 0.01$ \\
\hline Eicosapentanoic acid (g 100g-1) & $0.36 \pm 0.03$ \\
\hline Behenic acid (g 100g-1) & $0.10 \pm 0.00$ \\
\hline Docosahexanoic acid (g 100g ${ }^{-1}$ ) & $0.37 \pm 0.01$ \\
\hline Tricosylic acid (g 100g-1) & $0.10 \pm 0.00$ \\
\hline Lignoceric acid (g 100g-1) & $0.10 \pm 0.00$ \\
\hline Nervonic acid (g 100g ${ }^{-1}$ ) & $0.10 \pm 0.00$ \\
\hline Other fatty acids (g 100g $\mathrm{g}^{-1}$ ) & $0.41 \pm 0.01$ \\
\hline Saturated fats (g 100g ${ }^{-1}$ ) & $0.69 \pm 0.01$ \\
\hline Monounsaturated fats (g $100 \mathrm{~g}^{-1}$ ) & $2.02 \pm 0.04$ \\
\hline Polyunsaturated fats (g 100g-1) & $1.52 \pm 0.09$ \\
\hline Total omega (g 100g ${ }^{-1}$ ) & $1.14 \pm 0.07$ \\
\hline Total omega (g 100g-1) & $0.66 \pm 0.02$ \\
\hline Total Trans fats $\left({\mathrm{g} 100 \mathrm{~g}^{-1} \text { ) }}\right.$ & $0.00 \pm 0.00$ \\
\hline
\end{tabular}

\section{Conclusion:}

The proximal composition of the Croton wagneri flour demonstrated high fiber and protein content. Oleic acid was found the highest in the fatty acid analysis and there was a significant content of omega 3, omega 6, mono and polyunsaturated fats. The moshquera plant may be incorporated into foods to increase their nutritional value. Further research should be performed to investigate the full applications and uses of this plant. 


\section{Acknowledgements:}

Authors are grateful and would like to thank CENTROCESAL laboratories in Pichincha, Quito, Ecuador and LABONORT laboratories and Dr. Quim and Edison Miño in Ibarra, Imbabura, Ecuador.

\section{References:}

1. Altamirano Pérez, I. V. (2015). Evaluation of the antioxidant activity of four species of the genus Croton. Quito: UCE.

2. Akende, K.E., Abubakar, M.M., Adegbola, T.A., Bogoro, S.E. \& Doma, U.D. (2010). Chemical evaluation of the nutritive quality of pigeon pea (Cajanus cajan (L.) Millsp.) International journal of poultry science, 9(1):63-65.

3. Barrera, C. A. C. (2016). Medicinal importance of the genus Croton (Euphorbiaceae). Revista Cubana de Plantas Medicinales, 21(2).

4. Buitrago, J. A. (1990). Cassava in animal feed: CIAT.

5. Butt, M. and Batool, R. (2010). Nutritional and functional properties of some promising legumes protein isolates. Pakistan Journal of Nutrition, 9(4): 373-379.

6. De la Torre, L., Navarrete, H., Muriel, P., Macía, M. J., \& Balslev, H. (2008). Encyclopedia of Useful Plants of Ecuador (with data extract): QCA Herbarium of the Pontifical School of Biological Sciences.

7. Doménech Asensi, G., Durango Villadiego, A. M., \& Ros Berruezo, G. (2017). Moringa oleifera: Review of applications and uses in food. Latin American Archives of Nutrition, 67(2), 86-97.

8. Ghaly, A. E., \& Alkoaik, F. (2010). Extraction of protein from common plant leaves for use as human food. American Journal of Applied Sciences, 7(3), 331.

9. Giraldo, A., Velasco, R., \& Aristizabal, J. (2006). Obtaining flour from cassava leaves (Manihot esculenta Crantz) for human consumption. Biotecnología en el sector agropecuario y agroindustrial, 4(1), 33-42.

10. González, J., Pérez, J., Monan, M., \& Rodríguez, O. (2020). GC-MS Characterization of Ethanolic Extract from Croton wagneri Müll. Arg. Open Access Library Journal, 7(2), 1-9.

11. Howeler, R. H. (2002). Cassava mineral nutrition and fertilization. Cassava: Biology, production and utilization, 115-147.

12. Le Guerroué, J.-L., Douillard, R., Cereda, M. P., \& Chiarello, M. D. (1996). As proteínas de folhas de mandioca: aspectos fisiológicos, nutricionais e importância tecnológica. Bol. Centro Pesqui. Process. Aliment, 133-150.

13. Marcía Fuentes, J.A., Montero Fernández, I., Zumbado, H., LozanoSánchez, J., Santos Alemán, R., Navarro-Alarcón, M., Borrás-Linares, I. \& Saravia Maldonado, S.A. (2020). Quantification of Bioactive 
Molecules, Minerals and Bromatological Analysis in Carao (Cassia grandis). Journal of Agricultural Science, 4(1), 6-10. https://doi.org/10.5539/jas.v12n3p88.

14. Marcía Fuentes, J., Chavarría Carrión, L., \& Zumbado, H. (2019). Analysis of the process of yuca flour, on the sensory and nutritional properties of the casabe (Professional Article). Nexo Revista Científica, 32(1), 88-93. https://doi.org/10.5377/nexo.v32i01.7992

15. Navarro, C. L., Restrepo, D., Perez, J. (2014). Pigeon pea (Cajanus cajan) an alternative in the food industry. Biotecnología en el Sector Agropecuario y Agroindustrial, 12 (2): 197-206.

16. Ouborg, N., Piquot, Y., \& Van Groenendael, J. (1999). Population genetics, molecular markers and the study of dispersal in plants. Journal of Ecology, 87(4), 551-568.

17. Oyeyinka, A. T., \& Oyeyinka, S. A. (2018). Moringa oleifera as a food fortificant: Recent trends and prospects. Journal of the Saudi Society of Agricultural Sciences, 17(2), 127-136.

18. Pino, J. A., Terán-Portelles, E. C., Hernández, I., Rodeiro, I., \& Fernández, M. D. (2018). Chemical composition of the essential oil from Croton wagneri Müll. Arg.(Euphorbiaceae) grown in Ecuador. Journal of Essential Oil Research, 30(5), 347-352.

19. Rodríguez, J. J. B., \& Soriano, J. A. P. (2016). Evaluation of the degree of substitution of oatmeal (Avena sativa) and quinoa leaf flour (Chenopodium quinoa) to formulate an enriched biscuit. ingeniería: Ciencia, Tecnología e Innovación, 3(2), 96-120.

20. Rojas, L. C., Uribe, Y. H., Martínez, N. S., \& Niño, D. R. (2009). Preliminary phytochemical analysis of cupatá leaves, stems and seeds (Strychnos schultesiana Krukoff). Colombia forestal, 12(1), 161-170.

21. Sáez-Tonacca, L., Aravena-Narbona, A., \& Díaz Ramírez, C. (2018). Use of quinoa leaf flour (Chenopodium quinoa) as an innovative ingredient, for the preparation of food for human use. Idesia (Arica), 36(2), 233-242.

22. Sharapin, N. (2001). Vegetable raw materials for the phytopharmaceutical products industry. Revista de fitoterapia, 1(3), 197-203.

23. Soni, A., \& Sosa, S. (2013). Phytochemical analysis and free radical scavenging potential of herbal and medicinal plant extracts. Journal of Pharmacognosy and Phytochemistry, 2(4), 22-29.

24. Wargiono, J., Richana, N., \& Hidajat, A. (2011). Contribution of cassava leaves used as a vegetable to improved human nutrition in Indonesia. Cassava Research and Development in Asia: Exploring New Opportunities for an Acient Crop, 466. 
25. Win, D. T. (2005). Oleic acid-the anti-breast cancer component in olive oil. AU JT, 9(2), 75-78.

26. Zhofre, A. (2012). Forest Species of the Dry Forests of Ecuador. Ecuador: Ministry of the Environment Ecuador, 70-106. 